\title{
Managing medical emergencies: risks and responses
}

\section{Sue Stannard}

NIVA Course Leader, Medical Adviser, Norwegian Centre of Maritime and Diving Medicine, Bergen, Norway

Maritime emergencies of all types and magnitude occur on a regular basis. From ship wrecks to piracy, from fire to a medical emergency, there are many situations that can arise on board a ship that pose a risk to the seafarer, the ship itself, the ship owner and insurance company and the environment. However, as demonstrated in figures for the annual number of calls made from ships to the Norwegian authorities, the need for medical assistance is by far the most common reason that ships need external help and support. In 2014, 2379 calls out of a total of 6056 were for medical assistance. This may be for single or multiple casualties, for injury or illness, for passengers or crew [1]. In emerging data at Radio Medico Norway it can be seen that the volume of calls to Telemedical Assistance Services (TMAS) has remained constant over recent years with a significant proportion requiring medical evacuation.

At the end of 2017 there were articles published about the premature labour of a lady on board a Colour Line ferry last August [2] and about the helicopter evacuation of a person on board a DFDS ferry in November [3]. More recently there has been fire on board a container ship [4] and further stories can be found with an internet search!

A workshop in February 2015, organised by the International Maritime Health Association (IMHA) and sponsored by the ITF Seafarer's Trust, reviewed current experiences and identified challenges in the practical handling of a medical emergency at sea. A consensus was achieved and this was published as an IMHA position paper later that year [5]. It was noted that the training of ship's officers, the information available to them on board in terms of the International Medical Guide for Ships or national equivalent, and the equipment and medication on board were all far from optimal. The role of TMAS was also discussed and challenges to providing such a service were identified. It was agreed that ideally the management of such a situation should be a seamless process with full integration of all components to ensure that the management of a medical incident is optimal. The workshop also recognised that the management of a medical incident is itself part of a larger medical section of maritime risk management which includes the medical selection of seafarers, health and safety at sea, health promotion, medical incident management, TMAS support, evacuation if required, shore based care, repatriation and rehabilitation.

A major part of the health and safety at sea included in such a risk management system should be a system to assess the risk of an accident or illness occurring and to ensure the appropriate operational planning that will reduce the likelihood of such an incident occurring and mitigate the effect of such an incident should it occur. In other sectors of the maritime industry such risk assessment is more formally developed and within the shipping industry we may well be able to learn from experiences within the offshore petroleum industry and the military services.

There are many factors involved in risk management including but not limited to, regulation [6], TMAS, training, the safety and effectiveness of medical evacuation, port health care and repatriation. At the same time the ethics of the situation must be taken into consideration and the confidentiality of the seafarer maintained.

The impact of a medical emergency on board a vessel can be huge in terms of both personal and operational 'cost'. How best to manage this must include a discussion on how best to prevent it and mitigate the effects - the noble art of risk management.

As is often the case in the field of maritime and occupational medicine there are more questions than answers in this specific area. To address these questions and hopefully stimulate debate and progress, NIVA, in conjunction with the Norwegian Centre for Maritime and Diving Medicine and Seahealth Denmark are arranging a course in October 2018 entitled 'Managing Medical Emergencies at Sea: Risks and Responses' [7]. The course will be held in Elsinore, Denmark and will consider how such risks can be prevented and mitigated, both by action 
in advance of an incident and by effective management of emergencies when they arise. Approaches to predicting and assessing the likelihood of medical emergencies will be presented and methods for the critical analysis of the effectiveness with which they are managed will be discussed and evaluated. Risk assessment and risk management will be considered in an integrated way to enable participants to develop the skills for optimising procedures within the maritime sector and thus ensure safer working conditions for seafarers. I look forward to seeing many of your readers there.

\section{REFERENCES}

1. http://www.mariut.org/arskonferanser/arskonferanse-2015/ her-finner-du-konferansens-innlegg.

2. http://www.magasinetpax.no/lille-karl-ble-fodt-pa-color-fantasy/.

3. https://www.bt.dk/danmark/drama-paa-oslofaergen-midt-i-oeresund-redningshelikopter-sendt-afsted-person-bragt.

4. http://www.maritimedenmark.dk/Print.asp?ld=19491.

5. http://imha.net/images/stories/2015-02WS-LONDON.pdf.

6. Carter T, Stannard SL. Healthcare at sea: are regulations a guarantee of minimum standards or a barrier to improved practice. Int Marit Health. 2014; 65(4): 1-4.

7. https://niva.org/course/managing-medical-emergencies-sea-risks-responses/. 